\title{
The occurrence and distribution of megaspores in the Drybrook Sandstone and associated measures of the Forest of Dean basin, Gloucestershire, England
}

\author{
EDWIN SPINNER \\ Department of Geology, University of Sheffield, Mappin Street, Sheffield S1 3JD, England
}

\begin{abstract}
Megaspore assemblages are recorded from the Drybrook Sandstone and associated measures of the Forest of Dean basin, Gloucestershire, England, which support the miospore evidence described earlier by Sullivan (1964).
\end{abstract}

\section{INTRODUCTION}

The Forest of Dean is situated between the Wye and Severn valleys in Gloucestershire, England. In the centre of the area is a small coalfield, broadly triangular in outline. To the west and south lie the larger coalfields of South Wales and Bristol-Somerset (Fig. 1). Early study of the area suggested a small basin of Carboniferous rocks, the margins being formed by Lower Carboniferous strata overlain unconformably by Coal Measures. Detailed descriptions of the Coal Measures have been given by Trotter (1942), Moore (1954) and Welch \& Trotter (1961) in which three broad lithological divisions were recognised, Trenchard, Pennant and Supra-Pennant groups. Macrofossil evidence for the dating of the Coal Measures is limited. Non-marine Lamellibranchs restricted to the lower part of the succession suggest the Anthraconauta tenuis zone of the upper Coal Measures (as redefined by Stubblefield \& Trotter, 1957, p. 31). Plant macrofossils are more abundant and were first described by Arber (1912), who assigned them to "Upper Coal Measures", whereas Crookall (1955) equated them with upper Wesphalian C/Westphalian D. Moore (1947), Welch \& Trotter (1961) and Wagner \& Spinner $(1965,1972)$ considered the macroflora to be indicative of Westphalian D.

The Lower Carboniferous succession has been described in detail by Trotter (1942) and Welch \& Trotter (1961). Immediately above the main Lower Carboniferous limestone of the area, a sequence of mainly arenaceous deposits occur which were first named as the Drybrook Sandstone by Sibly (1912, p. 240). In the southern part of the basin a marine limestone occurs within this sequence and the fauna from this limestone indicates a Lower Carboniferous age $\left(S_{2}\right)$ for the sequence (Sibly, 1918; Sibly \& Reynolds, 1937). Later Trotter (1942, p. 15) proposed the name Drybrook Sandstone Group for the sequence, within which he recognised the Drybrook Limestone as separating upper and lower portions of arenaceous deposits. The formational names Upper Drybrook Sandstone and Lower
Drybrook Sandstone were proposed for these portions by Welch \& Trotter (1961, p. 59). The three formations were only clearly distinguished by Welch \& Trotter in the southern part of the basin. In the northern part of the basin, around the village of Drybrook, the arenaceous deposits were referred to as the Lower Drybrook Sandstone (op. cit., p. 65).

Palynological investigations of coals and shales from the succession within the basin have been reported by several workers. Miospore assemblages from the upper part (Coal Measures) by Smith \& Butterworth (1967) and Wagner \& Spinner (1972) indicating the Thymaspora obscura Assemblage XI, Westphalian D age. Spinner (1965) described the megaspore flora which indicated a similar age. Wagner \& Spinner (1972) discussed the impression, mio- and megaspore floras with floras from the type Westphalian D in Saar-Lorraine, upper Westphalian D to lower Stephanian of northwest Spain and drew attention to comparable floras in North America. Initial investigations of the Lower Carboniferous deposits were carried out by Allen (1960) and Lele \& Walton (1962) in conjunction with studies on macrofloral remains from an exposure of Drybrook Sandstone at Puddlebrook. A major contribution was made by Sullivan (1964). Sullivan described miospore assemblages from samples obtained from two horizons within the Drybrook Sandstone (?Lower Drybrook Sandstone of Welch \& Trotter, 1961) exposed in quarries on Plump Hill, approximately one mile east of Drybrook village (op. cit., p. 352-353, text-figs. 1-2).

The assemblages were rich in the number of taxa recorded but of very different composition. Sullivan concluded that the assemblage from the lower horizon (quarry A of Sullivan, p. 354) indicated a lower Upper Viséan age, which was in agreement with evidence provided earlier by the macrofauna of the Drybrook limestone. The other assemblage (quarry B of Sullivan, p. 354) was of much younger age, Westphalian A, lower to middle lenisulcata Zone in terms of the non-marine lamelli- 
branch scheme of classification. This was the first positive evidence for the presence of strata of low Westphalian age in the Forest of Dean, and Sullivan (p. 355) proposed the formational name Edgehills Sandstone to include the coal in quarry B (Edgehills coal) and associated conglomerates. This new palynological evidence had important stratigraphical implications which were dis- cussed by Sullivan (p. 384-389). Later, Neves et al. (1972, p. 348, fig. 1) in proposing a scheme of miospore zones for the British Dinantian considered Sullivan's assemblages from the Drybrook Sandstone (lower horizon) to be representative of their Perotrilites tessellatus-Schulzospora campyloptera TC zone. This note complements the work of Sullivan by describing

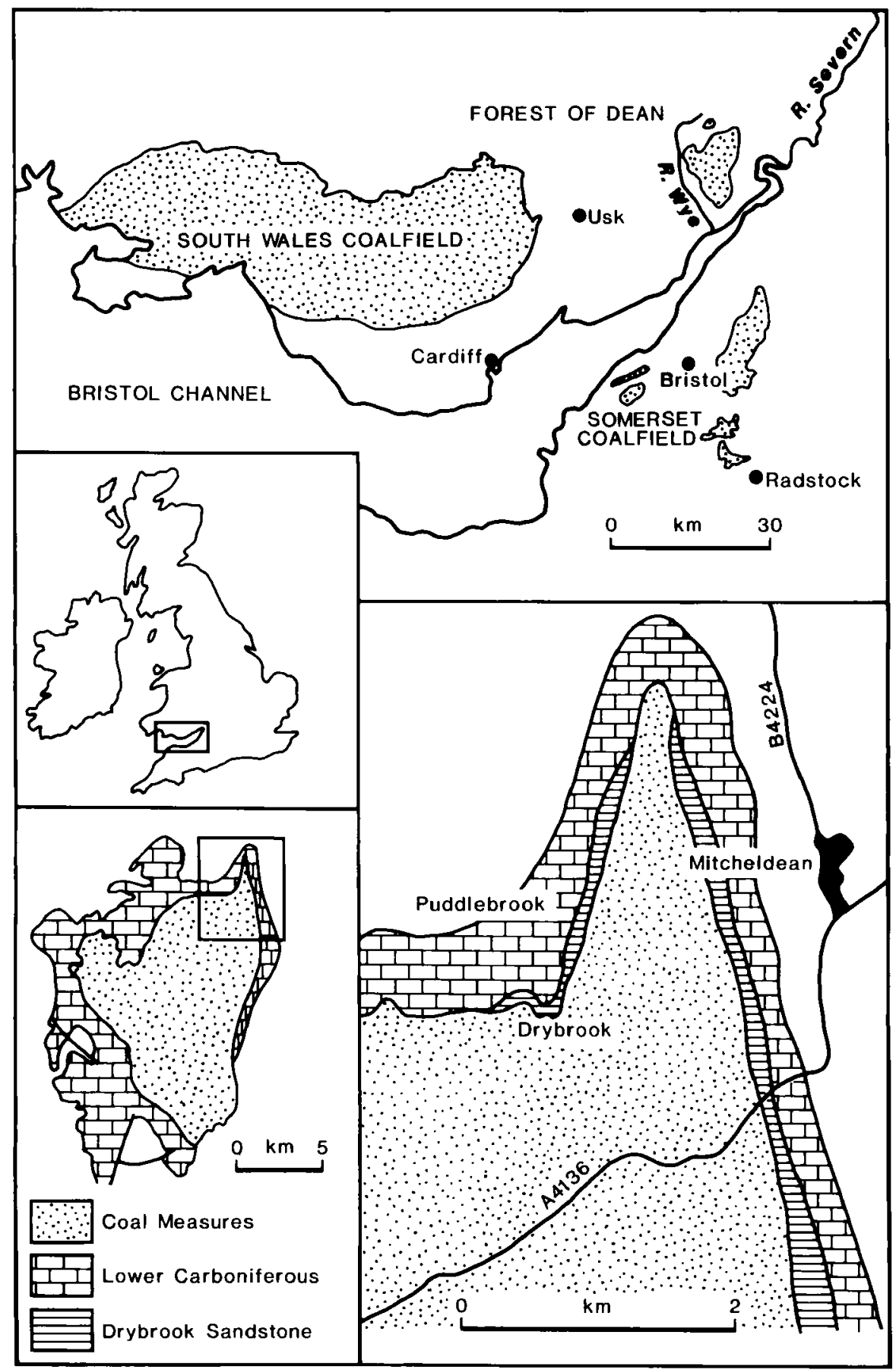

Fig. 1. Maps showing the position of the Forest of Dean, Drybrook and Plump Hill (based on Sullivan, 1964; Wagner \& Spinner, 1972). 
the megaspore assemblages which form part of the microflora. The rock samples are from the same horizons as Sullivan, the material having been stored in the collections of the Geology Department, University of Sheffield from the time of Sullivan's original work. The techniques used in preparation of the samples in the laboratory are similar to those of Sullivan, the main differences being in the time allowed for the action of acids, and the sieves used (mesh size $150 \mu \mathrm{m}$ ) to separate the coarse from the fine material after oxidation. The specimens illustrated here are representative of the assemblages and are stored in the reference collection, Micropalaeontology Laboratory, Geology Department, University of Sheffield.

\section{MEGASPORES FROM THE DRYBROOK SANDSTONE}

The assemblage obtained was of excellent preservation, very rich numerically, but restricted in the variety of taxa present. Three species, Didymosporites scotti Chaloner, 1958, Carbaneuletes circularis Spinner, 1983 and Cystosporites giganteus Schopf, 1938 formed the assemblage with occasional rare small sporomorphs lacking in distinctive features, which may represent denuded forms of Didymosporites or Carbaneuletes. Of these taxa, $D$. scotti and $C$. circularis provide complementary evidence to that of the miospores of an Asbian (T.C. miospore zone)-Dinantian age. C. circularis has been recorded from strata in northwest England of similar age (Butterworth \& Spinner, 1967; Spinner, 1983) and unpublished work by the author has revealed the presence of this taxon in strata of similar age from northeast England. D. scotti is well known from strata of Dinantian age in northern England, Scotland and Ireland (Chaloner, 1958; Butterworth \& Spinner, 1967). C. giganteus has a stratigraphic range spanning the Carboniferous (Dijkstra, 1946; Winslow, 1959) and is of little value.

MEGASPORES FROM THE EDGEHILLS COAL

The assemblage obtained was similar to that from the Drybrook Sandstone in the general characteristics of quality of preservation, abundance of specimens and lack of variety of taxa present. However, the taxa recorded were different, Cystosporites varius (Wicher) Dijkstra, 1946 being the dominant species. C. giganteus was also common, particularly the small abortive form. Two other distinctive forms of megaspore assignable to the genera Triangulatisporites (Potonié \& Kremp) emend. Karczewska, 1976 and Tuberculatisporites (Potonié \& Kremp) emend. Spinner, 1968 were also present in the assemblage. These two forms have been interpreted differently by workers in the past. Dijkstra (1946) only recognised two 'broad' species for these forms, Triletes triangulatus Zerndt and Triletes mamillarius Bartlett, while Potonié \& Kremp (1955-
56) and Karczewska (1976) differentiated genera containing several species. Study of the ornamentation of the specimens in this assemblage suggests the presence of two previously described species, Triangulatisporites regalis (Ibrahim) Potonié \& Kremp, 1956 and Tuberculatisporites apiculatus (Ibrahim) Potonié \& Kremp, 1955. These two species and $C$. varius are not known from strata older than Westphalian $\mathrm{A}$.

This assemblage is considerably different in content to those described earlier (Spinner, 1965) from the overlying Trenchard and Pennant groups (Westphalian D), particularly in the absence of species belonging to the genus Valvisisporites (Ibrahim) Potonié \& Kremp, 1954. V. nigrozonales (Stach \& Zemdt) Potonié \& Kremp, 1956 and $V$. sofiaense (Schopf, Wilson \& Bentall) Bhardwaj, 1957 having a stratigraphic range Westphalian B-D in Europe, and $V$. auritus (Zerndt) Potonié \& Kremp sensu Bhardwaj, 1957 being characteristic of Westphalian D strata.

The absence of any representatives of the lageniculate type of megaspore is unusual, for species such as Lagenicula subpilosa (Ibrahim) Potonié \& Kremp, 1955, Setosisporites hirsutus (Loose) Ibrahim, 1932 are well known from strata of Westphalian A age (Potonié \& Kremp, 1955). This may be a reflection of the ecology of the coal swamp.

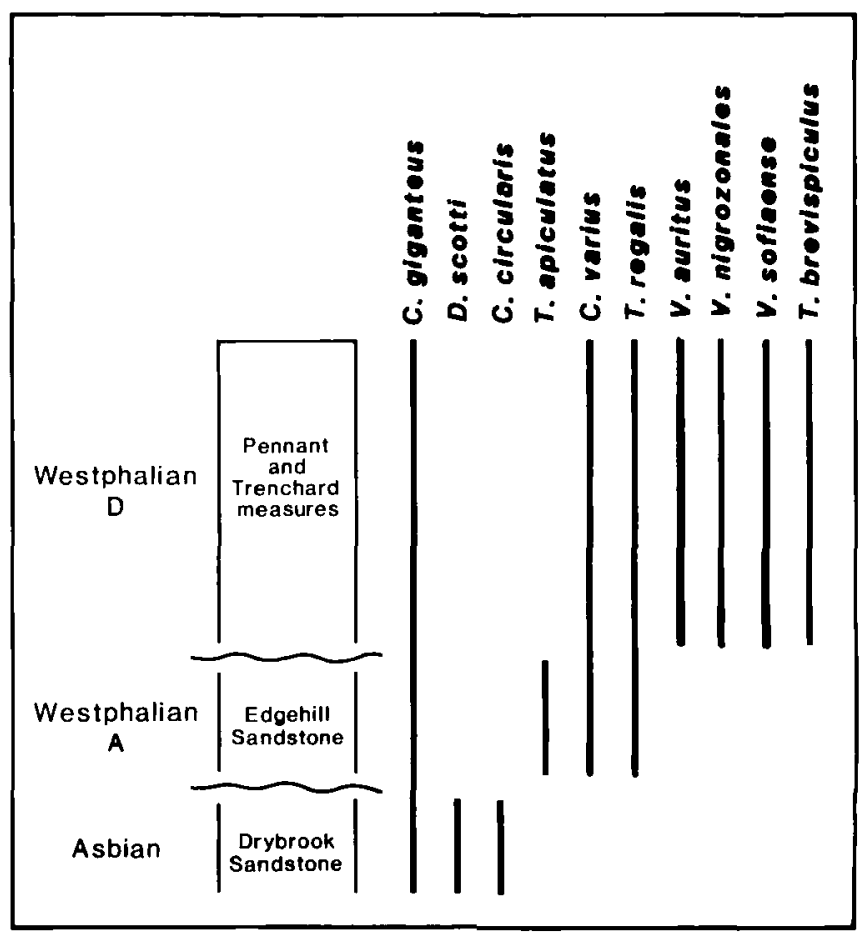

Fig. 2. Table showing the distribution of selected species of megaspores in the Forest of Dean basin. 


\section{REFERENCE}

Allen, K. C. 1960. Lepidostrobophyllum fimbriatum (Kidston 1883) from the Drybrook Sandstone (Lower Carboniferous). Geol Mag., London, 98, 225-229, pl. XII.

Arber, E. A. N. 1912. On the fossil flora of the Forest of Dean Coalfield (Gloucestershire) and the relationships of the coalfields of the West of England and South Wales. Phil. Trans. Roy. Soc. London (B), 202, 233-281.

Butterworth, M. A. \& Spinner, E. G. 1967. Lower Carboniferous spores from northwest England. Palaeontology, London, 10, 1-24, pls. 1-5.

Chaloner, W.G. 1958. Isolated megaspore tetrads of Stauropteris burntislandica. Ann. Bot. London (N.S.), 22, 197-204.

Crookall, R. 1955. Fossil plants of the Carboniferous of Great Britain. Mem. geol. Surv. G.B. (Palaeont.), 4, 1-84, pls. $1-24$

Dijkstra, S.J. 1946. Eine monographische Bearbeitung der karbonischern Megasporen. Meded. geol. Sticht., ser. C-III-I, 1, 1-101.

Karczewská, J. 1976. Megaspores of the Turma Zonales from the carboniferous of Poland, part II-Reconsideration of the genus Triangulatisporites. Acta Palaeontologica Polonica, Warszawa, 21, 333-363, pls. VI-XXVIII.

Lele, K. M. \& Walton, J. 1962. Fossil flora of the Drybrook Sandstone in the Forest of Dean, Gloucestershire. Bull. Br. Mus. Nat. Hist., London, (Geol.), 7, 137-152.

Moore, L. R. 1947. The sequence and structure of the southern portion of the East Crop of the South Wales Coalfield. Quart. J. Geol. Soc. London, 103, 261-300.

Moore, L. R. 1954. The Forest of Dean Coalfield. In Trueman, A E., The Coalfields of Great Britain, 126-133, Arnold, London.

Neves, R., Guienn, K. J., Clayton, G., Ioannides, N. \& Neville, R.S.W. 1972. A scheme of miospore zones for the British Dinantian. Compte Rendu 7 me Congr. Int. Stratigr. Géol. Carbonif., Krefeld (1971), 1, 347-353, 2 text-figs.

Potonié, R, \& Kremp, G. 1954. Die Gattungen der paläozoischen Sporae dispersae und ihre Stratigraphie. Geol. $J b$., Hanover, 69, 111-184, pls. 4-20.

Potonié, R. \& Kremp, G. 1955. Die sporae dispersae der Ruhrkarbons, ihre Morphographie und Stratigraphie mit Ausblicken auf Arten anderer Gebiete und Zeitabschnitte, Teil 1. Palaeontographica, London, 98B, 1-136, pls. 1-16.
Potonié, R. \& Kremp, G. 1956. Idem, Teil II. Ibid., 99B, 85-191, pls. 17-22.

Schopf, J. M. 1938. Spores from the Herrin (no. 6) coal bed in Illinois. Rep. Invest. Ill. St. geol. Surv., 50, 73 pp.

Sibly, T. F. 1912. The carboniferous succession in the Forest of Dean Coalfield. Geol. Mag., London, 49, 417-422.

Sibly, T. F. 1918. On the geological structure of the Forest of Dean. Ibid., 55, 23-28.

Sibly, T. F. \& Reynolds, S. H. 1937. The carboniferous limestone of the Mitcheldean area, Gloucestershire. Quart. J. Geol. Soc. Lond., 93, 23-57.

Smith, A.E.V. \& Butterworth, M. A. 1967. Miospores in the coal seams of the Carboniferous of Great Britain. Palaeontology, London, Spec. Pap. 1, 1-324, pls. 27.

Spinner, E. G. 1965. Westphalian D megaspores from the Forest of Dean Coalfield, England. Palaeontology, London, 8, 82-106, pls. 14-17.

Spinner, E. G. 1968. Contribution on the megaspore genus Tuberculatisporites (Ibrahim) Potonié \& Kremp, 1954. Pollen et Spores, X, 395-410, 3 pls.

Spinner, E. G. 1983. Some new sporomorphs from the Lower Carboniferous of N.W. England. Ibid., XXV, 117-129, 4 pls.

Stubblefield, C. J. \& Trotter, F. 1957. Divisions of the Coal Measures on Geological Survey maps of England and Wales. Bull. geol. Surv. G.B., 13, 1-5.

Sullivan, H.J. 1964. Miospores from the Drybrook Sandstone and associated measures in the Forest of Dean basin, Gloucestershire. Palaeontology, London, 7, 351-392, pls. $57-61$.

Trotter, F. M. 1942. Geology of the Forest of Dean Coal and Iron Ore Field. Mem. geol. Surv. G.B., 95 pp.

Wagner, R.H. \& Spinner, E. G. 1972. The stratigraphic implication of the Westphalian D macro- and microflora of the Forest of Dean Coalfield (Gloucestershire) England. Proceedings 24th International Geological Congress, Montreal, section 7, 428-437.

Welch, F. B. A. \& Trotter, F. M. 1961. Geology of the country around Monmouth and Chepstow. Mem. Geol. Surv. G.B., $164 \mathrm{pp}$.

Winslow, M. R. 1958. Upper Mississippian and Pennsylvanian megaspores and other plant micro-fossils from Illinois. Bull. Ill. St. geol. Surv., Urbana, 86, 102 pp.

\section{Explanation of Plate 1}

All figures illustrated by transmitted light.

Figs. 1-3. Tuberculatisporites apiculatus Potonié \& Kremp, 1955: fig. 1, polar compression $(\times 30)$; figs. 2, 3, enlargement illustrating ornament at margin and on distal surface of spore body $(\times 300)$.

Figs. 4-6. Triangulatisporites regalis Potonié \& Kremp, 1956: fig. 4, lateral compression $(\times 70)$; fig. 5, enlargement illustrating reticulate pattern of ornament of exine $(\times 500)$; fig. 6 , oblique lateral compression $(\times 70)$.

Fig. 7. Cystosporites giganteus.(Zerndt) Schopf, 1938, part of proximal area showing trilete mark $(\times 20)$.

Figs. 8, 9. Carbaneuletes circularis Spinner, $1983(\times 100)$.

Figs. 10, 11, Didymosporites scotti Chaloner, $1958(\times 100)$. 

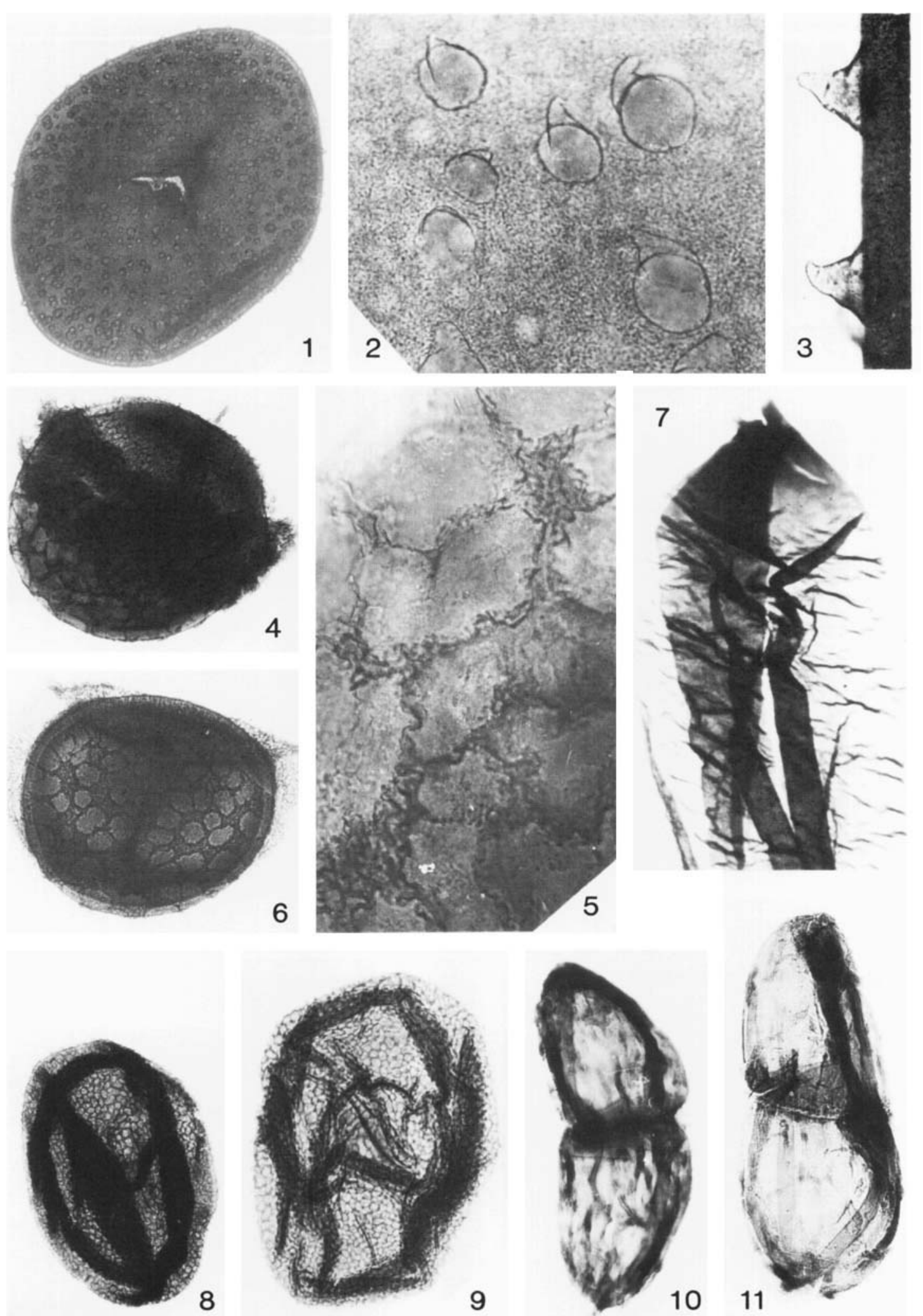